\title{
JUURNAL_RU
}

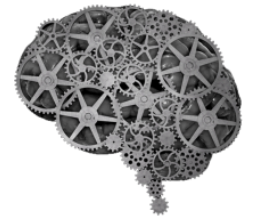

COMPANY GROUP "INTELLEKT"

Ключникова Е.Л. БашГУ

Уфа, Россия

doi: 10.18411/1j2016-5-3-06

\section{О формировании «концептуальной сетки» юрислингвистического метаязыка}

На сегодняшний день анализ языковых средств науки представляет особый интерес и приобретает специфическое значение, так как оно обусловлено многократным возрастанием объема научной информации. С каждым днем в науке совершаются все новые и новые открытия, требующие к себе определённой доли внимания в силу того, что любое научное знание отражение уровня развития человеческой культуры, жизни.

В целях объективности знания и в силу строгой однозначности, а также необходимости наука вынуждена пользоваться исключительно развитым знаковым арсеналом познания - языком науки. Язык - это форма существования знания в виде системы знаков, позволяющая отражать в сознании субъекта объекты действительности, а также позволяющая фиксировать, хранить и передавать информацию (научную) [1, с. 245-247]. Возникновение языка науки связано с развитием и совершенствованиемзнаковых форм фиксации практической цели: оторудий труда - первых знаковых форм фиксации цели осуществляетсяпереход к естественному языку, а затем к специальным языкамнауки[1, с.261].

Юрислингвистика -молодая наука, находящаяся в процессе научного становления и образовавшаяся на стыке двух гуманитарных наук - лингвистики, объектом которой выступает язык, и юриспруденции, объектом которой 
выступает право. За более чем 16-ти летнюю историю своего существования (в случае, если считать «отправной точкой» юрислингвистики введение самого термина «юрислингвистика» в 1999 году научным коллективом Лаборатории юрислингвистики и развития речи Алтайского госуниверситета и региональной ассоциацией лингвистов-экспертов и преподавателей (АЛЭП «Лексис»), под руководством профессора Н. Д. Голева)[2] юрислингвистика уже получила определенное методологическое обоснование, которое было закреплено в научных сборниках, статьях, диссертациях и даже учебных пособиях посредством использования естественного языка и специального языка (метаязыка) науки (юрислингвистики).

Метаязык (от греч. $\tau \alpha \mu \varepsilon \tau \alpha ́$ - “после”, “за” и язык; букв. - “некоторый язык о данном языке") - одно из важнейших понятий современной логики, математики, философии и методологии науки, семиотики и теоретической лингвистики. В самом общем смысле метаязык - любой естественный или искусственный язык (язык “второго уровня”), на котором описывается другойязык (язык “первого уровня”), служащий для описания предметов, свойств и ситуации окружающего мира либо тех или иных его областей или сфер[3].

Основой любого метаязыка (языка «второго уровня») является в первую очередь естественный язык, который служит условием существования языка науки; и лишь потом, при окончательном оформлении научной идеи, возникает потребностьфиксировать отображаемое знание в чистом виде на более точном языке - языке науки. Как известно, основой языка науки являются термины.«Термин - единица языка науки, выступает в качественепосредственной действительности научной мысли, ee материальнойосновы.»,термины - главная составная часть специализированного языка науки[1, с.268]. Терминология любой научной области (в частности и юрислингвистики),-это не просто список терминов, а семиологическая система, то есть выражение определенной системы понятий, в свою очередь отражающей 
определенное научное мировоззрение. Образование терминосистем является показателем завершения становления языка науки. Так как юрислингвистика еще находится на пути своего научного становления и формирования, отправной точкой в изучении метаязыка юрислингвистики можно считать изучение еe терминов, являющихся основой юрислингвистического терминологического аппарата, того терминологического инструментария, благодаря которому она функционирует (развивается, получает практическое использование и т.п.).

Во-первых, стоит отметить, что в метаязыке юрислингвистики используются термины не только из наук гуманитарного цикла (лингвистики, юриспруденции, социологии, психологии, культурологии, истории и т.п.), а также общенаучные термины (например, система, анализ и т.п.), но и из наук естественных (физики, биологии). Последнее обусловлено конкретным видом юрислингвистической деятельности - экспертизы, и, как следствие, разработкой ее методологической базы. Например, терминологическое сочетание «языковая экология» наглядно демонстрирует это. Однако, стоит отметить, что все же основу юрислингвистического специализированного языка образуют в первую очередь термины смежных наук - лингвистики и юриспруденции, во вторую очередь - это термины несмежных гуманитарных наук (социологии, психологии, культурологии, истории и т.п.), ну и, наконец,-общенаучные термины.

Во-вторых, стоит отметить неопределенное положениеюрислингвистического термина, т.е. такого термина, который был сформировался в новой отрасли знания - юрислингвистике. На данный момент развития юрислингвистики нет работ, посвященных этой проблеме, однако, осмелимся предположить, что ввиду своего столь молодого возраста наука еще просто не успела сформировать собственные термины, тем не менее, определенные сдвиги в этой сфере мы уже можем наблюдать. Например, термин «инвективность». Данный термин получил широкое исследование, в частности, проведенное специалистами сибирской ассоциации экспертов-лингвистов, а также специалистами лингвистов-экспертов Юга России, способствующих 
созданию первого словаря юрислингвистических терминов, где термин «инвективность» не находит своего непосредственного отображения, но участвует в отображении уже производного понятия «инвективой лексики». Так, под инвективой лексикой последние предлагают понимать «слова и выражения, заключающие в своей семантике, экспрессивной окраске и оценочном компоненте содержания интенцию (намерение) говорящего или пишущего унизить, оскорбить, обесчестить, опозорить адресата речи или третье лицо, обычно сопровождаемое намерением сделать это в как можно более резкой и циничной форме...» [4]. Говорить же о юрислингвистических терминах как об особом пласте метаязыка юрислингвистики пока что не предоставляется возможным ввиду объективных причин, связанных с развитием молодой науки.

В-третьих, стоит отметить тот факт, что на данный момент развития юрислингвистики предоставляется возможным исследовать некоторую «концептуальную сетку», ядро научного познания, представленное,в том числе и в виде серии продуктивных словообразовательных терминообразующих гнезд. Таким термином, к примеру, является термин «инвективность», довольно-таки часто используемый учеными и экпертами в сфере юрислингвистики. От термина «инвективность» образуются такие понятия и термины (терминологические сочетания) как «инвектор», «инвектум», «инвектогенность», «инвективный результат», «шкала инвективности», «инвективный сценарий». Такая словообразовательная продуктивность могла быть вызвана многими факторами, среди которых главнейшим является фактор запроса на отображение уже концептуально существующих, но не отображенных знаково понятий. 


\section{Литература:}

1. Ким В.В. Семиотика и научное познание: Философско-методологический анализ [Текст] / - Екатеринбург : Изд-во Урал, ун-та, 2008

2. Академик. Словари и энциклопедии. ЭР. http://dic.academic.ru/dic.nsf/ruwiki/705328

3. Новая философская энциклопедия: В 4 тт. М.: Мысль. Под редакцией В. С. Стёпина. 2001. ЭР. http://dic.academic.ru/dic.nsf/enc_philosophy/708/

4. Словарь юрислингвистических терминов. Ассоциация лингвистовэкспертов Юга России. ЭР. http://www.ling-expert.ru/slovar.html 